\title{
THE USE OF CIRC TO IMPROVE STUDENT'S READING ABILITY
}

\author{
Adriana ${ }^{1}$, Acep Haryudin ${ }^{2}$ \\ ${ }^{1}$ SMA YPKKP Bandung \\ ${ }^{2}$ IKIP Siliwangi \\ ${ }^{1}$ adri.sigma@gmail.com, ${ }^{2}$ haryacep@gmail.com
}

\begin{abstract}
The purpose of research was to find whether the learning model of the CIRC based on student learning was effective in improving reading ability in English learner. This activity aims to get experience in learning process and education activities that is used as a provision to become a candidate for educator. Researcher need to be able to have values, attitudes, knowledge and the skills needed as an english teacher. Research activities starts from observation to implementation in learning process in class and activity carried out after doing consultation with the teacher supervisor first and also guidance with the Lecturer Field Advisor. In teaching process the writer found in class that students need to improve their reading ability. That's why the writer use the titte in this journal is The Use Of Circ To Improve Student's Reading Ability. CIRC is Cooperative Integrated Reading and Composition. Implementation of this research was carried out in the class XI Manajemen Pemasaran SMK YPKKP Bandung.
\end{abstract}

Keywords: CIRC,Improve,Reading Abilitiy

\section{INTRODUCTION}

Reading is a activity by the reader to get the message outcome that conveyed by the author through the medium of words and sentences. If the meaning of words is not fulfilled, then the written and implied message will not be caught and the reading process will not be carried out properly. The aim of reading is to understand ideas or content in text, the ability to understand mean in reading as a whole, whether in the form of narration, descriptive, song or poetry that can be written or unwritten work. In other definition is to find and get information, including content, to know the mean of whole text.

Haryudin (2017) reading is one of the most important activities in human life. By reading, people can get a lot of information and they can also get lots of knowledge that enrich their mind in this globalization era. Reading ability seems to be important acquired by everyone. Logically, it can usually be gained by the process that occurs during the school time or any language classes. Rivers (1981:259) points out that reading is a most important activity in any language class, not only as a source of information and a pleasurable activity, but also as a means of consolidating and extending one's knowledge of the language.

Reading skills are very important to be mastered by students in terms of understanding the content of messages conveyed in English writing. By having good reading comprehension skills, students can develop the ability to understand any material and can easily achieve learning goals, and can also develop language mastery, a positive effect on developing students' vocabulary knowledge, students can be perfect in spelling at their writing, even can be a good writer in the future, and with good reading skills will come up with good ideas in finding solutions to problems contained in the writings that are read. 
According to Alderson (2000: 63-65) in Darmayanti (2013) what causes difficulty in texts is the way the text is written, its styles or features that make one text different from another. Expository texts are harder to process than narrative texts. The structures associated with stories (story grammars) seem to facilitate comprehension by allowing readers to quickly construct a model of the text. "English is complicated and really hard to say !""Ah, I must be shame to learn English at this age."Often we hear these sentences spoken by people around us. But, are these statements true? Is learning English difficult? Well, here we will discuss about the difficulties that you often encounter or experience when learning English in Indonesia.Things that are often found in the class certainly must be considered how the best solution in the right way of teaching. Good teaching method is also hard to findand seldomamong the educators. Teaching method should considered to be applied in teaching as systematic and effective procedure that created by teacher based on the teachers' learning experience. The method must be applicable and also fun in student learning process and the most important point is that the method should find the teacher and the students' roles in class properly.

The obligation of an English teacher is hopefully not only to do creative solutions about teaching skills, but also have ability to give motivation and enthusiasm for learning to students. There are so many methods in learning English including in this study is a cooperative learning method where this method is the student centre learning method. English teachers asmediators of teaching and learning in the classroom have a responsibility to enhanceskill in english and make students more active and fun in the learning process.

Based on the problems described above, CIRC is a one of learning method that is expected to be very effective in improving students 'ability to read English and to find out effectiveness of the CIRC learning model related to students' ability in understand English learning material.The scientific articles created are based on the results of PPL activities carried out by IKIP Siliwangi students during the August to November 2018 period at SMK YPKKP Bandung. This scientific work is a report on the application of relevant theories to better understand and / or answer the phenomena found in an educational institution in this case the Vocational School which was chosen by students and has received approval from IKIP Siliwangi as their place of internship.

\section{METHOD}

Problems that exist at least the author sees occur to the personality of cognitive and affective aspects. Where Cognitive is the intellectual ability of students in thinking, knowing and solving problems. In this cognitive aspect the students at SMA YPKKP have problems in how they understand the material presented especially in English language learning. The author observed from several questions that were mentioned using English where students tended not to be able to understand what they were hearing and of course only a few students were able to answer the questions.

For progress of students' learning, it depends much on the variety of teaching strategy, how teacher presents the materials and how teacher creates a good interaction with the students during teaching learning process as stated byRahmawati, Padmawati, and Ratminingsih (2014). In learning process hopely English teachers do not monotonous in teaching strategy which asked students to read the text presented or discussed in a book or display and then do some exercises. Teaching activities done by the English teachers were based all about doing the activities from English book.After that English teachers asked students to read the text, make translation it into bahasa, then try to answer all questions given from the book, and make 
discussion between teacher and all students together. Students should be bored and had negative view in learning english in this case reading learning. Students have a need in learn, they need to be in enjoyable and fun situation in class. In this case tacher need to make priority teaching method should be applicable and make enjoyable for students. Of course the main priority teacher still have to make achievement in goal of learning process by the method.

Then the author sees at students do not having a significant problem in attitudes, interests, motions and activity. All students giving good attention to the teacher while delivering material in class. And when the teacher asks to do the assignment in front of the class, the students do well even though their understanding is not too good. Through this study, the authors felt that the way of thinking and mastery from students in the material discussed should taught more better in other better method. Mubarok and Sofiana (2017) state In cooperative learning, teachers teach students collaborative or social skills so that they can work together more effectively (Larsenfreeman, 2003:159). This is why in cooperative learning, there will be a sharing ideas with other students and students could lead their team discussion.

Regarding the condition researcher need to do research in teaching reading .Why reading, researcher see the students condition hard to understand every single word in english so they also hard to speak in english. And researcher need to improve their capability by teaching reading to improve their mastery in english reading. Related to the research conducted, the writer will conduct a study using method named CIRC Cooperative Integrated reading and Composition.

CIRC technique is one of the cooperative learning methoddesigned to improve reading and writing skills in basic education. Based on the description above, as one of the learning models, CIRC Learning is based on workgroups and focuses on all components in the classroom and school environment to be designed so that all talks and learning take place in a pleasant and purposeful atmosphere to develop students' master in read and compile summaries based on the material they read, and actively use mathematical reasoning skills to solve problems.

Durukan (2011) stated cooperative integrated reading and composition (CIRC) technique, one of the learning techniques based on cooperation, is designed to develop reading, writing and other language skills in the upper grades of primary education. CIRC technique is developed to support traditionallyused "skill-based reading groups" approach. CIRC stands for Cooperative Integrated Reading and Compotition, including one model of cooperative learning that was originally an integrated cooperative teaching of reading and writing. In CIRC, students form in group learning to read and conduct discussions with the team reglated the material discussed which is cognitively involved, including reading cooperatively, giving definitions, and finding solutions, summaries, and directly adding their vocabulary words.

In the CIRC, students cooperate, interact, share material, and help each other to achieve the goal. Here, the students understand that they have different roles of specific tasks to allow opportunities for all group members to participate. It is a comprehensive program for teaching reading and writing in which students are assigned to teams composed of pairs of students from two or more different level,Parmawati(2010).In CIRC, students make cooperate and interact each other to achieve the goal. Here, students understand that they have different specific role roles to provide opportunities for all group members to contribute in understanding the material and completing the task and finding solutions to the problems found. 
Learning begins with the researcher delivering the material, goals, motivation followed by explaining the material. Then the students are grouped, each group consists of 4-5 people, students are given 1 or 2 questions in the form of worksheet to be done in groups. The teacher informs each group to read the questions to each other, interpret the contents of the questions, plan the completion of the questions, write down the solutions in a sequence, revise each other, and give up the group assignments to the teacher.

This activity needs to spend time for 20 minutes at the beginning of delivering the topic for each group. In this activity, the teacher makes several discussions related to the material in the group. In the discussion the teacher provides explanations and together helps students find solutions to each group's material problems; after the activity goes well the teacher lets students in the group work together to try to explore the material again. The teacher provides training to make text procedures related to students' daily activities such as making or doing something to students to make videos related to their work.

The obstacles experienced in the learning of the experimental class are the new learning models that make students have to adjust themselves first in order to be able to study well. Many students do not understand the meaning of the activities carried out in each group. At the first meeting many students were still embarrassed to go forward, ask questions, and agree. There is a group that does not pay attention when other groups present in front of the class. Learning in the teacher control class explains the material, gives examples of problems and how to solve them. Students are given practice questions and asked to do them. Some students are asked to work on the board. In this study many students do not pay attention to the teacher's explanation. This learning makes students passive. They cannot develop their knowledge. Their participation in contemporary learning. They are reluctant to ask questions, argue, and move forward to do the questions in writing.

\section{RESULTS AND DISCUSSION}

\section{Results}

The Improvement of English reading skills had achieved by the CIRC learning method. The CIRC method used during the study showed a significant increase in value was given to students during the research carried out PLP activities in high school YPKKP Bandung. This finding proves a significant difference in values at pretest and posttest. This research was conducted by learning English reading.

In pretest the scores of all students were not very good. During one meeting treatment was carried out with the CIRC method, all students got a significant development in the score of the posttest. The score of students test got significant improvement after students had treatment using CIRC learning method. Based on the result of the pretest score, the conclusion of this method found there is a significant difference score in reading scorein the students who are taught by using CIRC strategy.

The score of the pretest and posttest can be seen below in the table

Table 1

\begin{tabular}{ccc}
\hline Students & Pretest Score & Posttest Score \\
\hline 1 & 19 & 70 \\
2 & 35 & 89 \\
3 & 19 & 78 \\
\hline
\end{tabular}




\begin{tabular}{ccc}
\hline 4 & 48 & 96 \\
5 & 35 & 92 \\
6 & 47 & 94 \\
7 & 35 & 84 \\
8 & 56 & 69 \\
9 & 19 & 68 \\
10 & 21 & 73 \\
11 & 46 & 80 \\
12 & 50 & 94 \\
13 & 30 & 94 \\
14 & 38 & 96 \\
15 & 11 & 74 \\
16 & 40 & 92 \\
17 & 45 & 88 \\
18 & 23 & 78 \\
19 & 38 & 94 \\
20 & 21 & 74 \\
21 & 40 & 96 \\
22 & 21 & 70 \\
23 & 43 & 91 \\
24 & 29 & 96 \\
25 & 44 & 100 \\
26 & 33 & 98 \\
27 & 38 & 92 \\
28 & 50 & 98,3 \\
29 & 43 & \\
Mean & 34,1 & 96 \\
& & 89 \\
\hline
\end{tabular}

From the result of this research, it can be concluded that the implementation of CIRC strategy gives a good achievement in the reading comprehension. Based on the result stated previously, this research can be concluded that the application of CIRC strategy gave a better achievement in reading achievement than the conventional strategy.

\section{Discussion}

CIRC Method is one of cooperative approachin learning to improve reading and writing.In As rearcher explained above that students in CIRC are taught to make forms learning groups to learn together with friends and make discussion to find solution. CIRC as a cooperative method and student center in teaching reading in the elementary and secondary classes. The students work in teams to read each other, make predictions and conclusions about the text so that all students in the group are easier and more pleasant in understanding the material. Students also work in their teams to master other understanding ideas and skills.

Student activity that stands out in Cooperative CIRC learning is that students are increasingly enthusiastic in completing assignments given by the teacher, dare to present the results of the work in front of the class, and many students ask questions and think. This can be seen from the results of the student observation sheet that the assessment of each meeting has increased. There were those in the class who applied control learning, enthusiastic and courageous students in presenting the results of their work in front of the class tended to remain. Students are less 
enthusiastic and don't even care about completing the assignments given by the teacher and still don't dare to ask questions and present the results of the work in the classroom. Besides that, in the class that implemented Cooperative Learning-based CIRC learning active and directed cooperation was established.

\section{CONCLUSION}

Based on the discussion above, it is known that students in the class that use the CIRC learning model based on Cooperative Learning have improved students reading ability, the score in posttest was better than score in pretest with the Cooperative Learning-based CIRC learning model. The score of students postest in implementing CIRC learning improve after getting one meeting treatment. This shows that all indicators of effectiveness in this study have been fulfilled. So, the implementation of Cooperative Learning based CIRC learning models is effective on students' students reading abilities in English learning. Based on the results of the study regarding the effectiveness of the Students Learning-based CIRC model on the english reading abilities of YPKKP Class XI high school students, it can be concluded that the implementation of student learning-based CIRC learning models is effective towards improving student reading skills.

\section{ACKNOWLEDGMENTS}

In write this journal, a lot of people have provided motivation, advice, and support for the researcher. In this chance, the researcher intended to express his gratitude and appreciation to all of people who make many support and contribution for this research.

First of all here I need to thank to Alloh SWT and Rasululloh SAW who had give many blessed in my life without stop and i need to thanks to my lovely family especially to 2 beautiful angels in my live my mother who never stop to stand and pray for me and also my wife who always support and always stand with me anywhere and time, my lovely son and daughter and of course for my mother who always give me many pray for my whole life. And I need to give my grateful thanks to my kindly lecturer Mr. Acep Haryudin. M.Pd for his supervision, advice, correction and guidance from the very early stage of this research as well as giving me extraordinary experiences throughout the past few years. until the completion of this journal.

I gratefully thank to the principal of SMA YPKKP for allowing me to conduct the research there. Also to the English teachers in SMA YPKKP whom Ican't tell all of them here and the special one to Mr. Adi Triawan for allowing me to conduct my research in his class. I could never have finished this without your great guidance.

\section{REFERENCES}

Darmayanti. 2013. "The Implementation of Cooperative Integrated Reading and Composition (CIRC) Method In Teaching Narrative Text To Improve Students' Reading Comprehension At The Eleventh Grade Students Of Man 2 Model Makassar." Durukan, Erhan. 2011. "Effects of Cooperative Integrated Reading and Composition (CIRC) Technique on Reading-Writing Skills." Educational Research and Reviews 6(1):102-9. Haryudin. 2017. "The Effects of Reading Habit Towards Students ' Reading Comprehension At Private Senior High Schoolin Purwakarta." 57-70.

Mubarok, Husni and Nina Sofiana. 2017. "Cooperative Integrated Reading and Composition (CIRC) and Reading Motivation: Examining The Effect on Students' Reading Ability." 
Lingua Cultura 11(2):121.

Parmawati, A. (2018). The Study Correlation Between Reading Habit And Pronunciation Ability At The Second Grade Students Of Ikip Siliwangi. Eltin Journal, Journal Of English Language Teaching In Indonesia, 6(1), 46-52.

Rahmawati, L., Nyoman Padmawati, and Made Ratminingsih. 2014. "The Effect of Circ

Strategy and Achievement Motivation Toward Students ' Reading Comprehension.” E-

Journal Program Pascasarjana Universitas Pendidikan Ganesha 3(1980):1-12. 